\title{
Effect of genistein on basal jejunal chloride secretion in RII7H CF mice is sex and route specific
}

This article was published in the following Dove Press journal:

Clinical and Experimental Gastroenterology

30 January 2015

Number of times this article has been viewed

\author{
Esa Rayyan' \\ Sarah Polito' \\ Lana Leung' \\ Ashesh Bhakta' \\ Jonathan Kang' \\ Justin Willey' \\ Wasim Mansour' \\ Mitchell L Drumm² \\ Layla Al-Nakkash' \\ 'Department of Physiology, Arizona \\ College of Osteopathic Medicine, \\ Midwestern University, Glendale, AZ, \\ USA; ${ }^{2}$ Pediatric Pulmonology Division, \\ Case Western Reserve University, \\ Cleveland, OH, USA
}

Correspondence: Layla Al-Nakkash Department of Physiology, Midwestern University, 19555 N 59th Avenue, Glendale, AZ 85308, USA

$\mathrm{Tel}+\mathrm{I} 6235723719$

Fax + I 6235723673

Email lalnak@midwestern.edu
Abstract: Cystic fibrosis (CF) results from the loss or reduction in function of the CFTR (cystic fibrosis transmembrane conductance regulatory protein) chloride channel. The third most common CFTR mutation seen clinically is R117H. Genistein, a naturally occurring phytoestrogen, is known to stimulate CFTR function in vitro. We aimed to determine whether route of administration of genistein could mediate differential effects in $\mathrm{R} 117 \mathrm{H}$ male and female CF mice. Mice were fed (4 weeks) or injected subcutaneously ( 1 week) with the following: genistein $600 \mathrm{mg} / \mathrm{kg}$ diet $(600 \mathrm{Gd})$; genistein-free diet $(0 \mathrm{Gd})$; genistein injection $600 \mathrm{mg} / \mathrm{kg}$ body weight $(600 \mathrm{Gi})$; dimethyl sulfoxide control (0Gi). In male R117H mice fed $600 \mathrm{Gd}$, basal short circuit current $\left(\mathrm{I}_{\mathrm{sc}}\right)$ was unchanged. In $600 \mathrm{Gd}-$ fed female mice, there was a subgroup that demonstrated a significant increase in basal $\mathrm{I}_{\mathrm{sc}}\left(53.14 \pm 7.92 \mu \mathrm{A} / \mathrm{cm}^{2}, \mathrm{n}=6, P<0.05\right)$ and a subgroup of nonresponders $\left(12.05 \pm 6.59 \mu \mathrm{A} / \mathrm{cm}^{2}, \mathrm{n}=4\right)$, compared to $0 \mathrm{Gd}$ controls $\left(29.3 \pm 6.5 \mu \mathrm{A} / \mathrm{cm}^{2}, \mathrm{n}=7\right)$. In R117H mice injected with $600 \mathrm{Gi}$, basal $\mathrm{I}_{\mathrm{sc}}$ was unchanged in both male and female mice compared to $0 \mathrm{Gi}$ controls. $\mathrm{I}_{\mathrm{sc}}$ was measured in response to the following: the adenylate cyclase activator forskolin (10 $\mu \mathrm{M}$, bilateral), bumetanide $\left(100 \mu \mathrm{M}\right.$, basolateral) to indicate the $\mathrm{Cl}^{-}$secretory component, and acetazolamide $\left(100 \mu \mathrm{M}\right.$, bilateral) to indicate the $\mathrm{HCO}_{3}{ }^{-}$secretory component; however, there was no effect of genistein (diet or injection) on any of these parameters. Jejunal morphology (ie, villi length, number of goblet cells per villus, crypt depth, and number of goblet cells per crypt) in R117H mice suggested no genistein-mediated difference among the groups. Serum levels of genistein were significantly elevated, compared to respective controls, by either $600 \mathrm{Gd}$ (equally elevated in males and females) or $600 \mathrm{Gi}$ (elevated more in females versus males). These data suggest a sex-dependent increase in basal $\mathrm{I}_{\mathrm{sc}}$ of $\mathrm{R} 117 \mathrm{H}$ mice and that the increase is also specific for route of administration.

Keywords: genistein, intestine, secretion, $C F T R, \mathrm{R} 117 \mathrm{H}$

\section{Introduction}

Genistein is a naturally occurring isoflavonic phytoestrogen, found in high concentrations in soy products. ${ }^{1}$ We and others have demonstrated genistein's ability to stimulate the cystic fibrosis transmembrane conductance regulator (CFTR) chloride $\left(\mathrm{Cl}^{-}\right)$channel in isolated cells, ${ }^{2-5}$ and intact isolated tissues. ${ }^{6-10}$ Both wild-type (Wt) $\mathrm{CFTR}^{5}$ and the most common cystic fibrosis (CF) disease-associated mutation ( $\triangle$ F508-CFTR) are known to be stimulated by genistein. ${ }^{11,12}$ Genistein increases the open probability of $\Delta$ F508-CFTR to levels analogous to those seen with Wt CFTR, ${ }^{11,12}$ thus indicating a potential therapeutic benefit of genistein designed for CF treatment.

The effectiveness of genistein in improving the function of $\triangle F 508-C F T R$ in in vitro cell systems, with half-maximal effective concentration $\left(\mathrm{EC}_{50}\right)$ of $5 \mu \mathrm{M}$, is 
within the physiological range achievable via diet. ${ }^{2,13}$ Indeed, micromolar concentrations of genistein can be measured in serum. ${ }^{14}$ Mice consuming $750 \mathrm{mg} / \mathrm{L}$ genistein have been shown to generate plasma genistein concentrations of $\sim 2 \mu \mathrm{M},{ }^{15}$ and moreover, we have previously shown that a diet containing genistein $600 \mathrm{mg} / \mathrm{kg}$ food $(600 \mathrm{Gd})$ for 4 weeks yields serum concentrations of $\sim 4-8 \mu \mathrm{M}$ in Wt female and male mice, ${ }^{8}$ yielding levels that are comparable to a soy milk diet in humans. ${ }^{16}$

Use of genistein as a pharmacological tool to manipulate tissue function has been demonstrated in several systems: 1) Noël et $\mathrm{al}^{17}$ have demonstrated that subcutaneous (sc) injection of $50 \mu \mathrm{M}$ genistein (or MPB-07), in the presence of isoprenaline $(10 \mu \mathrm{M})$, induced salivary secretion in $\mathrm{Cftr}^{+/+}$ mice; 2) acute bilateral application of genistein increases short circuit current $\left(\mathrm{I}_{\mathrm{sc}}\right)$, ie, increases anion secretion, in $\mathrm{Wt}$ murine distal colon; ${ }^{18} 3$ ) acute application of genistein has been shown to increase current and conductance in depolarized colonic mucosa of normal and CF mice. ${ }^{19}$ We have previously shown that exposure to dietary genistein $(600 \mathrm{Gd}$, for 4 weeks) stimulated basal $\mathrm{Cl}^{-}$secretion across freshly isolated segments of jejunum from Wt female mice, but not in male mice. $^{8}$ More recently, we have demonstrated that daily sc injections of genistein $(600 \mathrm{mg} / \mathrm{kg}$ body weight, $600 \mathrm{Gi}$ ) for periods of 1-2 weeks, elicit stimulation of basal $\mathrm{Cl}^{-}$secretion across freshly isolated segments of jejunum from $\mathrm{Wt}$ female and male mice. ${ }^{20,21}$

The clinically relevant CFTR missense mutation, R117H (replacement of arginine by histidine at residue 117), has a wide range of phenotypic variability and is included in many mutation panels for newborn screening. This membranespanning mutation reaches the plasma membrane - ie, the protein is correctly processed - but does not function appropriately, ie, the protein exhibits defective conduction (class IV) and gating (class III) abnormalities. ${ }^{22,23}$ These $\mathrm{R} 117 \mathrm{H}$ mice have been shown to have beneficial responses to a synthetic triterpenoid, CDDO (2-cyano-3,12-dioxooleana1,9(11)-dien-28-oic acid), as indicated by significant improvements in markers for airway disease. ${ }^{24}$ Interestingly, relatively recent evidence suggest that the $\mathrm{R} 117 \mathrm{H}$ mutation has little impact on $\mathrm{Cl}^{-}$secretion from freshly isolated human rectal biopsies nor on nasal $\mathrm{Cl}^{-}$secretion. ${ }^{25}$

Additional evidence suggests that beneficial effects of genistein on CFTR-mediated $\mathrm{Cl}^{-}$secretion may be a result of 1) either potentiation of the CFTR $\mathrm{Cl}^{-}$channel by binding to CFTR and the stabilization of the CFTR channel into its open state ${ }^{13}$ or 2 ) the promotion of CFTR retention in the plasma membrane. ${ }^{26}$ To date, there have been no studies to assess the effect of dietary genistein or daily sc genistein injections on intestinal function in $\mathrm{R} 117 \mathrm{H} \mathrm{CF}$ mice. In this study, we have compared the effects of 4 week consumption of a genistein-enriched diet (600Gd) or a genistein-free diet (0Gd) with the effects of 1 week treatment consisting of daily sc injections of genistein (600Gi) or vehicle control $(0 \mathrm{mg} / \mathrm{kg}$ body weight/day, 0Gi) on small intestinal (jejunal) epithelial anion secretion (transepithelial short circuit current, I , using freshly excised intestinal segments) in R117H female and male mice. In addition, we examine the effect of genistein on intestinal morphology. Based on our previous work describing genistein's action on $\mathrm{Wt}$ jejunal $\mathrm{Cl}^{-}$secretion, we predict that genistein would increase intestinal $\mathrm{I}_{\mathrm{sc}}$ in $\mathrm{R} 117 \mathrm{H}$ male and female mice to likely intermediate levels to those that we have previously noted in $\mathrm{Wt}$ female mice fed the same genistein-containing $\operatorname{diet}^{8}$ or the levels in $\mathrm{Wt}$-male and $\mathrm{Wt}$ female mice injected with the same genistein dose..$^{20}$

\section{Materials and methods \\ Mice}

Male and female mice carrying the R117H CFTR mutation were generously provided by the CF Mouse Models Core at Case Western Reserve University (Cleveland, OH, USA) and were housed in an animal care facility with 12:12-hour lightdark cycle, two mice per cage, until used. Mice consumed food and water ad libitum. Body weight was measured weekly during the studies and general health was monitored daily. Mice were randomly assigned to either genistein-containing diet (600 mg genistein/kg food, 600Gd) or genistein-free ( $0 \mathrm{mg}$ genistein $/ \mathrm{kg}$ food, $0 \mathrm{Gd}$ ) diet and were fed either of these two diets for 4 weeks. Mice of a separate subgroup were randomly assigned to either genistein-injected $(600 \mathrm{mg}$ genistein/kg body weight, 600Gi) or dimethyl sulfoxide (DMSO) control-injected group (0Gi) for a period of 1 week. Mice were asphyxiated in an atmosphere of $100 \% \mathrm{CO}_{2}$, followed by surgical thoracotomy to induce pneumothorax. Animal care and treatments were conducted in accordance with established guidelines, and all protocols were approved by the Midwestern University Institutional Animal Care and Use Committee.

\section{Diets}

Casein-based diets were purchased from Dyets Inc. (Bethlehem, PA, USA) and contained either $600 \mathrm{Gd}$ or $0 \mathrm{Gd} .^{8}$ Importantly, diets contained equivalent amounts of protein (20.3 g), carbohydrate (66 g), and fat (5 g), with an estimated energy content of $16.28 \mathrm{~kJ} / \mathrm{g}$. Diets were formulated as a powder and mice were allowed to free feed. All mice assigned 
to the injection studies were fed genistein-free (0Gd) diet. Diet composition is described previously in the study by Al-Nakkash et al. ${ }^{8}$

\section{Bioelectric measurement of intestinal secretion}

Via an abdominal incision, $\sim 5 \mathrm{~cm}$ of middle portion of jejunum was removed and placed in ice-cold oxygenated Krebs bicarbonate ringer (KBR) buffer. Each mouse yielded three to four jejunum pieces, isolated as described previously. ${ }^{18,27-29}$ Jejunum sections mounted in the Ussing chambers had $0.3 \mathrm{~cm}^{2}$ exposed surface area. Transepithelial short circuit current $\left(\mathrm{I}_{\mathrm{sc}}\right.$, reported as $\left.\mu \mathrm{A} / \mathrm{cm}^{2}\right)$ was measured via an automatic voltage clamp (VCC-600; Physiologic Instruments, San Diego, CA, USA) and the experimental conditions and methods were as previously described. ${ }^{8,20,21,30}$ Intestinal tissue pieces were constantly maintained in $1 \mu \mathrm{M}$ indomethacin (minimizing tissue exposure to endogenously generated prostanoids due to manipulation and mounting of the tissue). ${ }^{31}$ Glucose $(10 \mathrm{mM})$ was added to the serosal KBR bath and mannitol $(10 \mathrm{mM})$ was substituted for glucose in the mucosal KBR bath to avoid an inward current due to $\mathrm{Na}^{+}$-coupled glucose transport. ${ }^{30}$ Once mounted, the serosal side was exposed to tetrodotoxin $(0.1 \mu \mathrm{M})$, minimizing variations in intrinsic intestine neural tone. ${ }^{32}$ Intrinsic neural tone limits the absorptive capacity of the murine mucosa and neural block is denoted by a decrease in $\mathrm{I}_{\mathrm{sc}}$.

\section{Experimental protocols}

Tissues were exposed to KBR buffer for 20 minutes and steady-state basal $I_{s c}$ was measured at that time. Cyclic adenosine monophosphate-dependent anion secretion was assessed by bilateral application of $10 \mu \mathrm{M}$ forskolin (at 20 minutes) and steady-state forskolin response was measured at 50 minutes. Addition of bumetanide $(100 \mu \mathrm{M}$, serosal $)$, a $\mathrm{Na}^{+} / \mathrm{K}^{+} / 2 \mathrm{Cl}^{-}$cotransporter, evaluates the $\mathrm{Cl}^{-}$secretory component. Addition of acetazolamide $(100 \mu \mathrm{M}$ bilateral $)$ assesses the secretory component represented by $\mathrm{HCO}_{3}^{-}$. At the end of each experiment, glucose (10 mM, mucosal) was added to stimulate $\mathrm{Na}^{+}$-coupled glucose transport to assess tissue viability (denoted by $>10 \%$ increase in $\mathrm{I}_{\mathrm{sc}}$ ). In a subgroup of mice, basal $\mathrm{I}_{\mathrm{sc}}$ was determined, and at time 20 minutes, $100 \mu \mathrm{M}$ of phosphodiesterase inhibitor was added (bilateral), and at time 40 minutes, $200 \mu \mathrm{M}$ was added. Tissues that failed to respond to glucose within this parameter were discarded. Experiments were performed in the presence of $\mathrm{KBR}$ buffer $\left(\mathrm{Cl}^{-} / \mathrm{HCO}_{3}{ }^{-}\right.$present), containing the following (in $\mathrm{mM}$ ): $115 \mathrm{NaCl}, 25 \mathrm{NaHCO}_{3}, 5 \mathrm{KCl}, 1.2 \mathrm{MgCl}_{2}$, and 1.2 $\mathrm{CaCl}_{2}, \mathrm{pH} 7.4$.

\section{Histology and morphology}

Freshly isolated pieces of jejunum were embedded and flash frozen in Optimal Cutting Temperature compound (TissueTek OCT compound; Sakura Finetek USA, Torrance, CA, USA). Frozen sliced sections $(8-10 \mu \mathrm{m})$ of murine jejunum were stained with a standard hematoxylin and eosin protocol, prior to performing the morphometric analyses to evaluate basic histological measurements. In brief, sections were exposed to the following wash protocol: hematoxylin 30 seconds, water rinse 10 seconds, Scott's solution 5 seconds, water rinse 10 seconds, $95 \%$ ethanol 5 seconds, eosin 15 seconds, rinses with 95\% ethanol 10 seconds, $100 \%$ ethanol rinse 10 seconds, followed by treatment with Histo-Clear for 15 seconds. Crypt depth, villi length, and numbers of goblet cells per crypt and villus were measured using AxioVision LE (Carl Zeiss, freeware), from images of hematoxylin-and-eosin-stained jejunum sections. All images were taken at $\times 10$ magnification. Averages of measurements were taken from six separate slices per frozen section of jejunum (ie, per mouse), with data being presented as the average of seven mice per group.

\section{Serum genistein}

At the time the mice were euthanized, blood samples were obtained by cardiac puncture, and the serum was separated by centrifugation and then stored at $-80^{\circ} \mathrm{C}$. Serum samples were analyzed for genistein level by high-performance liquid chromatography using a modification of the methodology of Franke et al. ${ }^{33}$ Values represent the average of duplicate serum samples.

\section{Chemicals}

Forskolin was purchased from Calbiochem (La Jolla, CA, USA) and stored as a $10 \mathrm{mM}$ stock in DMSO at $-20^{\circ} \mathrm{C}$. Genistein was purchased from LC Laboratories (Woburn, MA, USA) and acetazolamide was purchased from MP Biomedicals (Solon, OH, USA). All other chemicals were obtained from Sigma-Aldrich (St Louis, MO, USA).

\section{Statistics}

Data are expressed as mean \pm standard error of mean (SEM). Numbers in parentheses are numbers of tissues used from separate individual mice. One-way analysis of variance with Newman-Keuls multiple comparison test or $t$-tests was performed using GraphPad (GraphPad Software, Inc. 
La Jolla, CA, USA), and $P<0.05$ was considered statistically significant.

\section{Results}

\section{Mouse weights and serum genistein}

During the 4 week diet and 1 week injection studies, mouse weights were monitored (Table 1). As shown in Table 1, significant increases in weight (from start weight) were observed in females fed $0 \mathrm{Gd}$ and in a subgroup of females fed $600 \mathrm{Gd}$. Interestingly, there was no difference in the final body weight of females fed 600Gd that concomitantly exhibited an increase in basal $\mathrm{I}_{\mathrm{sc}}$ (responders) versus those that did not have increased basal $\mathrm{I}_{\mathrm{sc}}$ (nonresponders). Mice in the injection study did not gain as much weight as those on the diet studies, likely due to the fact that diet mice were fed and maintained for additional duration (4 weeks on the diet study versus the 1 week injection studies).

Serum genistein concentrations are shown in Figure 1. Serum genistein levels were significantly elevated by genistein treatment in both male and female mice, regardless of route of administration (diet or injection). Of note, in both male and females alike, diet route of administration yielded significantly greater serum genistein levels compared to the injected counterparts. Interestingly, there was no difference in the serum genistein level of those females fed $600 \mathrm{Gd}$ that concomitantly exhibited an increase in basal $\mathrm{I}_{\mathrm{sc}}$ (responders: $740.3 \pm 271.7 \mathrm{ng} / \mathrm{mL}, \mathrm{n}=3$ ) versus those that did not have increased basal $I_{\text {sc }}$ (nonresponders: 1094.8 \pm 592.1 $\mathrm{ng} / \mathrm{mL}, \mathrm{n}=4)$.

Table I Effect of genistein on RI I7H body weights

\begin{tabular}{|c|c|c|c|}
\hline & $\begin{array}{l}\text { Start body } \\
\text { weight (g) }\end{array}$ & $\begin{array}{l}\text { End body } \\
\text { weight (g) }\end{array}$ & $\begin{array}{l}\text { Delta body } \\
\text { weight (g) }\end{array}$ \\
\hline Males, 0Gd & $26.92 \pm 1.05(9)$ & $28.26 \pm 1.73(9)$ & $1.33 \pm 0.88$ (9) \\
\hline Males, 600Gd & $25.86 \pm I .17(8)$ & $26.85 \pm 1.43(8)$ & $0.99 \pm 0.54(8)$ \\
\hline Females, 0Gd & $|8.28 \pm 0.4|(7)$ & $20.02 \pm 0.44(7)^{*}$ & 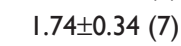 \\
\hline $\begin{array}{l}\text { Female responders, } \\
600 \mathrm{Gd}\end{array}$ & $20.40 \pm 1.49(6)$ & $22.32 \pm 2.03(6)$ & $1.92 \pm 0.94(6)$ \\
\hline $\begin{array}{l}\text { Female } \\
\text { nonresponders, } \\
600 \mathrm{Gd}\end{array}$ & $|8.6| \pm 0.83(4)$ & $19.98 \pm 0.65(4)^{*}$ & $1.36 \pm 0.25$ (4) \\
\hline Males, 0Gi & $19.82 \pm 0.47(5)$ & $20.3 I \pm 0.32(5)$ & $0.49 \pm 0.32(5)$ \\
\hline Males, $600 \mathrm{Gi}$ & $20.53 \pm 0.99(5)$ & $20.76 \pm 1.14(5)$ & $0.23 \pm 0.22(5)$ \\
\hline Females, 0Gi & $|8.09 \pm 0.7|$ & $|6.84 \pm| .2 \mid(5)$ & $-1.25 \pm 0.93$ \\
\hline Females, $600 \mathrm{Gi}$ & $|6.09 \pm 0.5|(5)$ & $16.19 \pm 0.66$ & $0.10 \pm 0.73(5)$ \\
\hline
\end{tabular}

Notes: Body weights were measured for both female and male RI I 7H mice assigned to one of four groups: fed 600Gd for 4 weeks, fed 0Gd for 4 weeks, injected with 600Gi for I week, or injected with 0Gi for I week. Data are expressed as mean \pm SEM. Numbers in parentheses are numbers of mice per group. *Significant increase from start body weight, $P<0.05$.

Abbreviations: $600 \mathrm{Gd}, 600 \mathrm{mg}$ genistein/kg diet; 0Gd, genistein-free diet; $600 \mathrm{Gi}$, $600 \mathrm{mg}$ genistein/kg body weight; $0 \mathrm{Gi}$, dimethyl sulfoxide control; SEM, standard error of the mean.

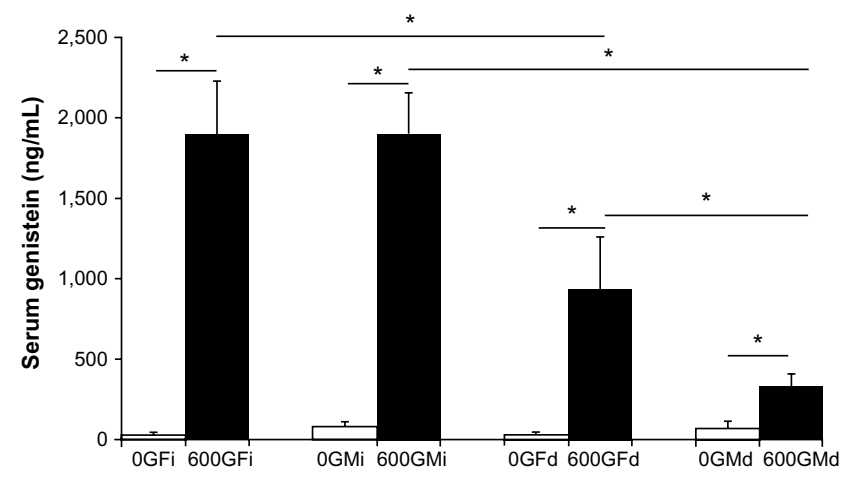

Figure I Effect of genistein treatment on serum genistein levels in R I I7H mice. Notes: Average serum genistein concentrations nanograms per milliliter $(\mathrm{ng} / \mathrm{mL})$ are shown for each of the groups tested: $0 \mathrm{Gd}, 600 \mathrm{Gd}, 600 \mathrm{Gi}$, or $0 \mathrm{Gi}$. Values are mean \pm SEM. *Significant difference, $P<0.05, n=6-9$ per group.

Abbreviations: $600 \mathrm{Gd}, 600 \mathrm{mg}$ genistein/kg diet; 0Gd, genistein-free diet; 600Gi, $600 \mathrm{mg}$ genistein/kg body weight; $0 \mathrm{Gi}$, dimethyl sulfoxide control; SEM, standard error of the mean ; i, injected; d, diet; G, genistein; F, female; M, male.

\section{Ussing chamber bioelectric measurements Diet study}

Basal $\mathrm{I}_{\mathrm{sc}}$ was significantly increased in a subgroup of female mice fed $600 \mathrm{Gd}$ for 4 weeks $\left(53.14 \pm 7.92 \mu \mathrm{A} / \mathrm{cm}^{2}, \mathrm{n}=6\right)$ compared to those fed $0 \mathrm{Gd}\left(29.30 \pm 6.47 \mu \mathrm{A} / \mathrm{cm}^{2}, \mathrm{n}=7, P<0.05\right.$; Figures 2 and $3 \mathrm{~A}$ ). Interestingly, another subgroup of female mice fed $600 \mathrm{Gd}$ for 4 weeks did not exhibit an increase in basal $I_{\text {sc }}\left(12.05 \pm 6.59 \mu \mathrm{A} / \mathrm{cm}^{2}, \mathrm{n}=4\right.$; Figure 2). Moreover, we found that basal anion secretion in jejuna removed from male mice fed $600 \mathrm{Gd}$ for 4 weeks $\left(39.20 \pm 11.72 \mu \mathrm{A} / \mathrm{cm}^{2}\right.$, $\mathrm{n}=9$ ) was comparable to those from male mice fed $0 \mathrm{Gd}$ $\left(34.89 \pm 7.67 \mu \mathrm{A} / \mathrm{cm}^{2}, \mathrm{n}=9\right.$; Figure $\left.3 \mathrm{~A}\right)$. The effect of bilateral application of $10 \mu \mathrm{M}$ forskolin was determined, and steadystate forskolin-stimulated $\mathrm{I}_{\mathrm{sc}}$ was significantly increased only in the subgroup of females that had exhibited a significantly elevated basal $\mathrm{I}_{\mathrm{sc}}$ (Figure 3B). Addition of bumetanide (100 $\mu \mathrm{M}$, serosal), to assess the $\mathrm{Cl}^{-}$secretory component, only resulted in a significant increase in the percentage inhibition with bumetanide in the subgroup of $600 \mathrm{Gd}$ females with elevated basal $\mathrm{I}_{\mathrm{sc}}$ (Figure 3C). There was no effect of acetazolamide $(100 \mu \mathrm{M}$, bilateral $)$ on the $\mathrm{HCO}_{3}^{-}$contribution toward the $\mathrm{I}_{\mathrm{sc}}$, in any of the groups (Figure 3D).

\section{Injection study}

Basal $I_{s c}$ was unchanged after 1 week of daily genistein injections (600Gi), compared to $0 \mathrm{Gi}$ controls, for both male and female R117H mice (Figure 4A). In R117H mice, in either sex with either $600 \mathrm{Gi}$ or $0 \mathrm{Gi}$, we found no change in $\mathrm{I}_{\mathrm{sc}}$ following the addition of bilateral application of $10 \mu \mathrm{M}$ forskolin, bumetanide (100 $\mu \mathrm{M}$, serosal), or acetazolamide (100 $\mu \mathrm{M}$, bilateral) (Figure 4B-D). 


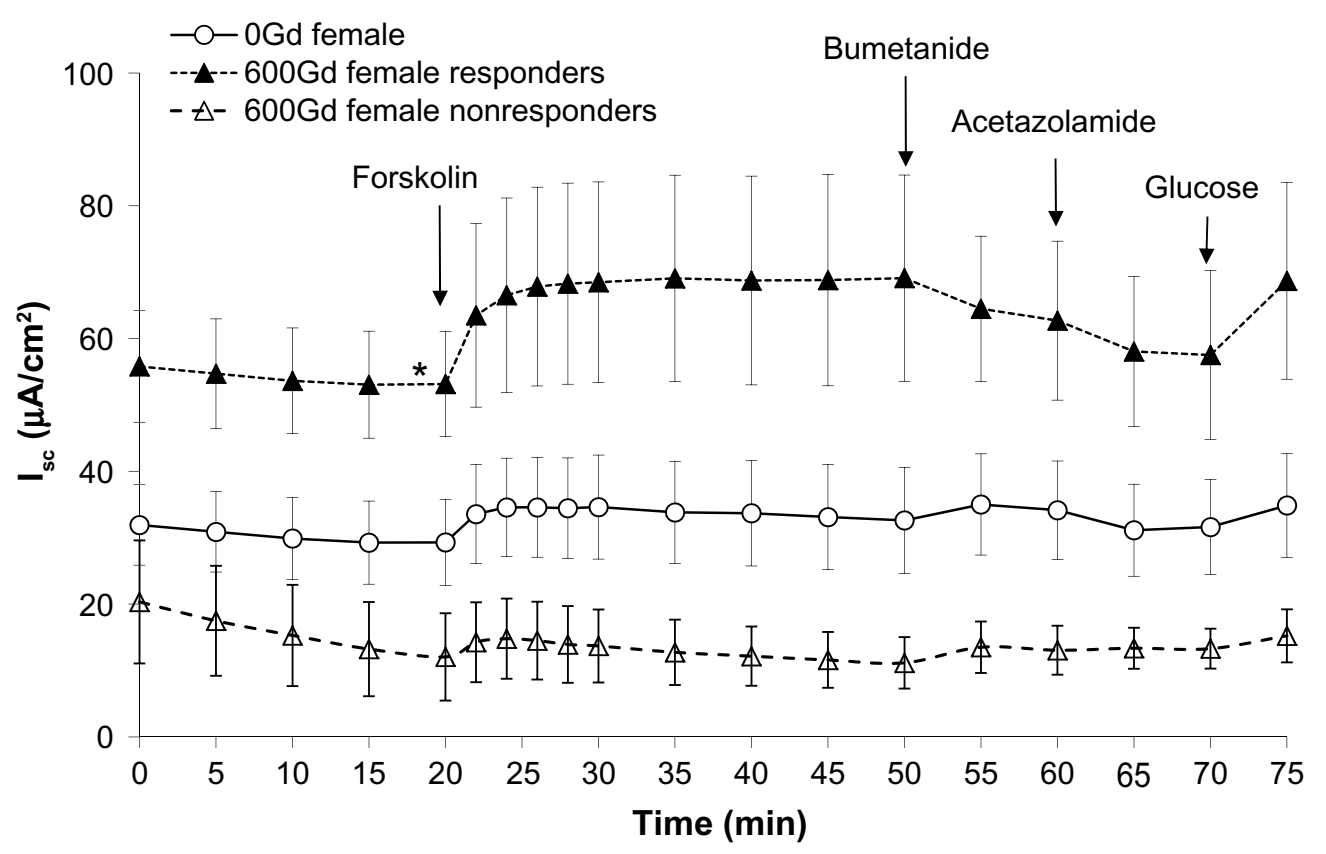

Figure 2 Effect of a 4 week genistein diet $(600 \mathrm{Gd})$ on average $\mathrm{I}_{\mathrm{sc}}$ in jejunum from $\mathrm{RI}$ I $7 \mathrm{H}$ female mice.

Notes: Average basal $\mathrm{I}_{\mathrm{sc}}$ and total $\mathrm{I}_{\mathrm{sc}}$ in the presence of forskolin (10 $\mu \mathrm{M}$, bilateral), bumetanide ( $100 \mu \mathrm{M}$, serosal), acetazolamide (I00 $\mu \mathrm{M}$, bilateral), and glucose (I0 mM, mucosal). Female RI I 7H mice were fed 600Gd (closed triangle $\boldsymbol{\Delta}$, responders, $\mathrm{n}=6$ ), 600Gd (open triangle $\Delta$, nonresponders, $\mathrm{n}=4$ ), or 0Gd ( $\mathrm{O}$, $\mathrm{n}=7$ ) diet for 4 weeks. Values are mean \pm SEM. *Significant difference from $0 G d, P<0.05$.

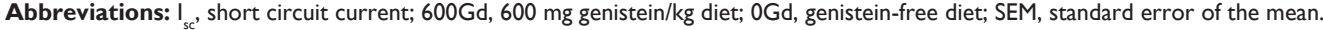

\section{Role of phosphodiesterase enzymes}

To determine the role of phosphodiesterase enzymes on basal $\mathrm{I}_{\mathrm{sc}}$ in R117H male and female mice, we examined the effect of IBMX (3-isobutyl-1-methylxanthine, a nonspecific phosphodiesterase enzyme inhibitor, bilateral). Despite a trend for an increased $\mathrm{I}_{\mathrm{sc}}$ following addition of IBMX, there was no significant effect of either $100 \mu \mathrm{M}$ or $200 \mu \mathrm{M}$ IBMX on basal $\mathrm{I}_{\mathrm{sc}}$ in male and female jejuna (Figure 5), likely due to the large variability in the responses between mice. There was a trend for a greater increase in $\mathrm{I}_{\mathrm{sc}}$ with IBMX in females versus males, but again, large variability nullified this potential effect.

\section{Jejunum histology}

To determine whether there were genistein-mediated or sex-dependent effects on intestinal morphology, histological sections of jejunum were stained using hematoxylin and eosin and analyzed for wall thickness, villi length, crypt depth, and numbers of goblet cells within entire villi and crypts using Axiovision software. Data are shown in Table 2, and representative hematoxylin-and-eosin-stained histological images are shown in Figure 6. Number of goblet cells per villus was significantly greater in the female $0 \mathrm{Gd}$ group compared to their male counterparts $(P<0.05)$, which may indicate a greater mucus production in $\mathrm{R} 117 \mathrm{H}$ females versus males, that were fed the casein-based genistein-free diet.
There were no other effects of sex or genistein (regardless of route of administration) on the parameters measured.

\section{Discussion}

We provide here the first evidence that chronic consumption of dietary genistein (600Gd, for 4 weeks) increases basal $\mathrm{I}_{\mathrm{sc}}$ in freshly isolated jejunum segments removed from a population of female $\mathrm{R} 117 \mathrm{H}$ mice, but not in $\mathrm{R} 117 \mathrm{H}$ males.

Dietary isoflavones (such as genistein) are found in soy and are digested in an average daily diet. Soy-rich diets can generate micromolar serum genistein concentrations. ${ }^{34}$ Consumption of genistein-containing diets correlates with elevated serum levels of genistein: $1 \mu \mathrm{M}$ serum genistein concentrations can be obtained in rats consuming a diet of $750 \mu \mathrm{g}$ genistein $/ \mathrm{g} /$ day ${ }^{35}$ and serum levels of $\sim 1.5 \mu \mathrm{M}$ or $\sim 0.5 \mu \mathrm{M}$ serum genistein in mice have been detected after consumption of 1,000 or $500 \mathrm{mg} / \mathrm{kg}$ dietary genistein, respectively, for 4 weeks. ${ }^{36}$ Moreover, we have previously demonstrated that $\mathrm{Wt}$ female and $\mathrm{Wt}$ male mice fed $600 \mathrm{Gd}$ for 4 weeks have serum genistein levels of $\sim 8 \mu \mathrm{M}$ and $\sim 4 \mu \mathrm{M}$ respectively, which correlated with a significant genisteinmediated increase in basal $\mathrm{I}_{\mathrm{sc}}$ in females $\left(\sim 36 \mu \mathrm{A} / \mathrm{cm}^{2}\right)$, but not in males. ${ }^{8}$ Furthermore, we have recently demonstrated that serum genistein levels significantly increased in both 600Gi-treated females (after 1 week to $\sim 9 \mu \mathrm{M}$ ) and 600Gitreated males (after 2 weeks to $\sim 4 \mu \mathrm{M}$ ), and this translated 
$\mathbf{A}$

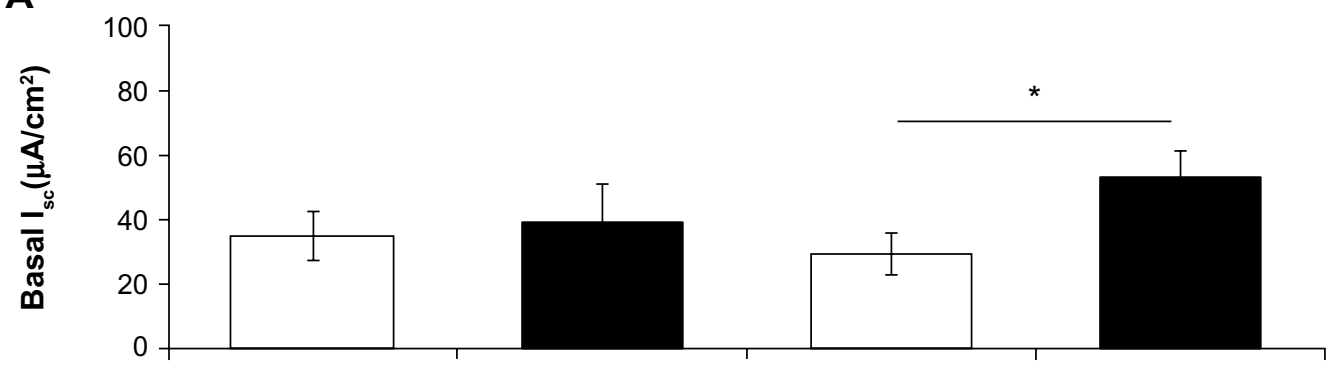

B
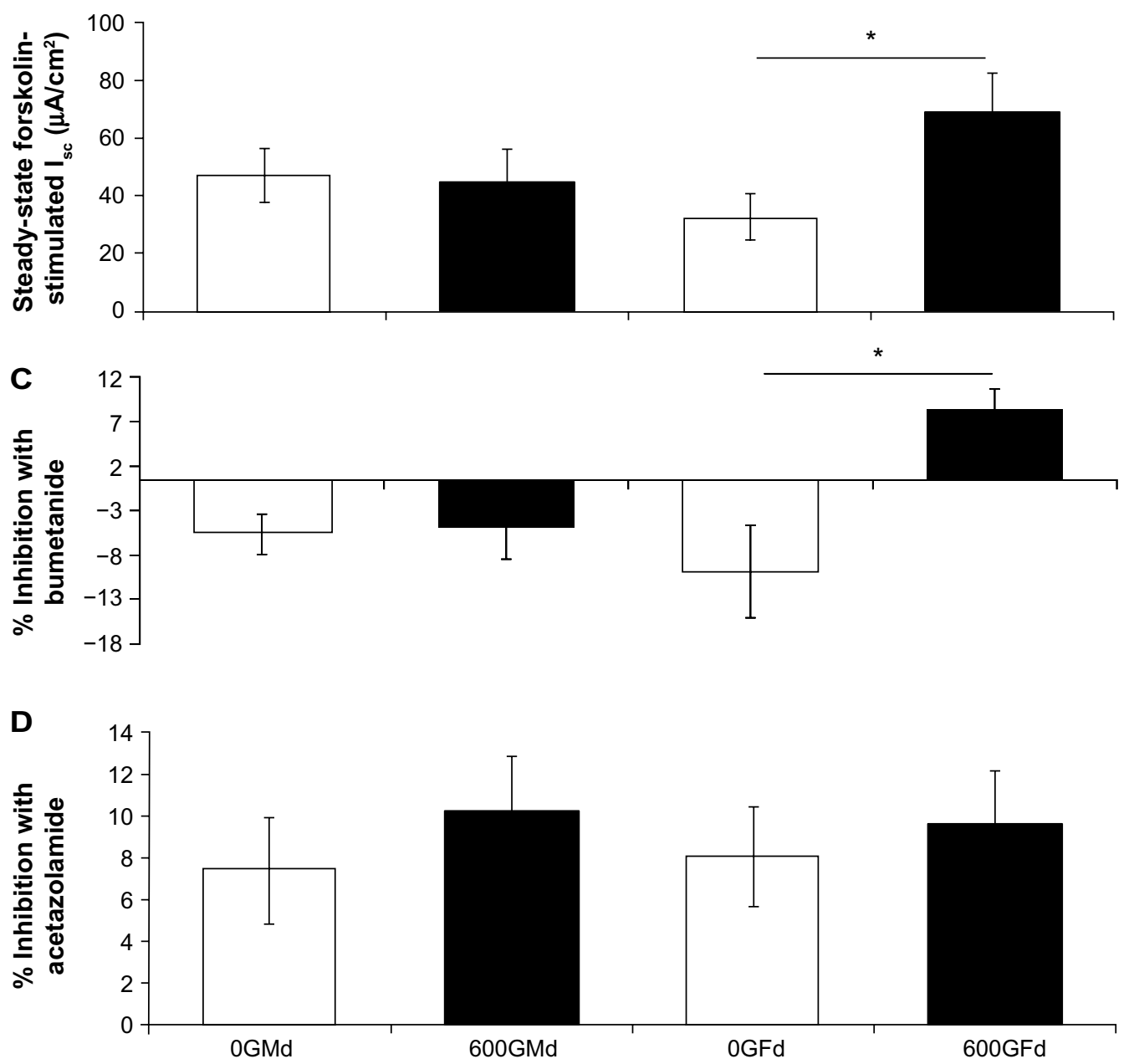

Figure 3 Effect of a 4 week genistein diet $(600 \mathrm{Gd})$ on average $\mathrm{I}_{\mathrm{sc}}$ in jejunum from RII $7 \mathrm{H}$ mice.

Notes: (A) Average basal $I_{s c}$ from the RII7H male (M) and female (F) mice, fed either 600Gd or 0Gd. (B) Average steady-state forskolin-stimulated (I0 $\mu$ M, bilateral) $\mathrm{I}_{\mathrm{sc}}$ from male and female mice fed $600 \mathrm{Gd}$ or 0Gd. (C) Percentage inhibition of steady-state forskolin-stimulated I by bumetanide (I00 $\mu$ M, serosal). (D) Percentage inhibition of steady-state forskolin-stimulated $\mathrm{I}_{\mathrm{sc}}$ by acetazolamide ( $100 \mu \mathrm{M}$, bilateral). Values are mean $\pm \mathrm{SEM}$. $*$ indicates significant difference, $P<0.05, \mathrm{n}=6-9$ per group.

Abbreviations: $I_{s c}$, short circuit current; $600 \mathrm{Gd}, 600 \mathrm{mg}$ genistein $/ \mathrm{kg}$ diet; 0Gd, genistein-free diet; SEM, standard error of the mean.

into significant genistein-mediated increases in basal $\mathrm{I}_{\mathrm{sc}}$ (of $\sim 85 \mu \mathrm{A} / \mathrm{cm}^{2}$ ) in both Wt females and Wt males. Thus, in Wt mice, sc injections produced similar potentiative effects on basal jejunal $\mathrm{I}_{\mathrm{sc}}$ in both female and male mice, and, moreover, these increases in $\mathrm{I}_{\mathrm{sc}}$ were considerably greater than the increases seen via the diet route of administration. This was not the case with the $\mathrm{R} 117 \mathrm{H}$ mice, and while serum genistein levels were substantially greater in 600Gi-treated males and females, basal $I_{s c}$ was not modified. We demonstrate here that serum genistein levels in $\mathrm{R} 117 \mathrm{H}$ males and females injected with $600 \mathrm{Gi}$ are significantly greater compared to the levels found after dietary route of administration, $600 \mathrm{Gd}$. Moreover, R117H female mice fed genistein diet have significantly greater serum genistein levels $(942 \pm 319 \mathrm{ng} / \mathrm{mL}, \mathrm{n}=7)$ 


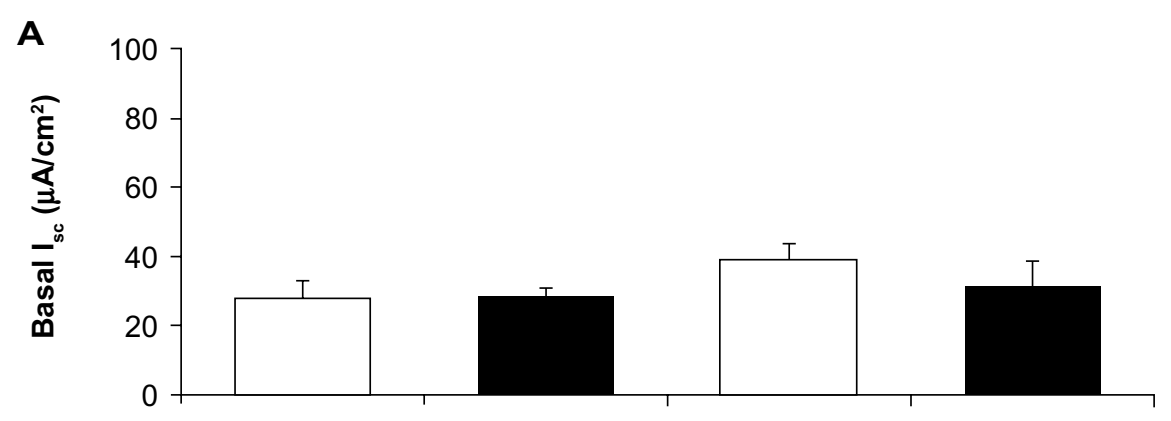

$\mathbf{B}$
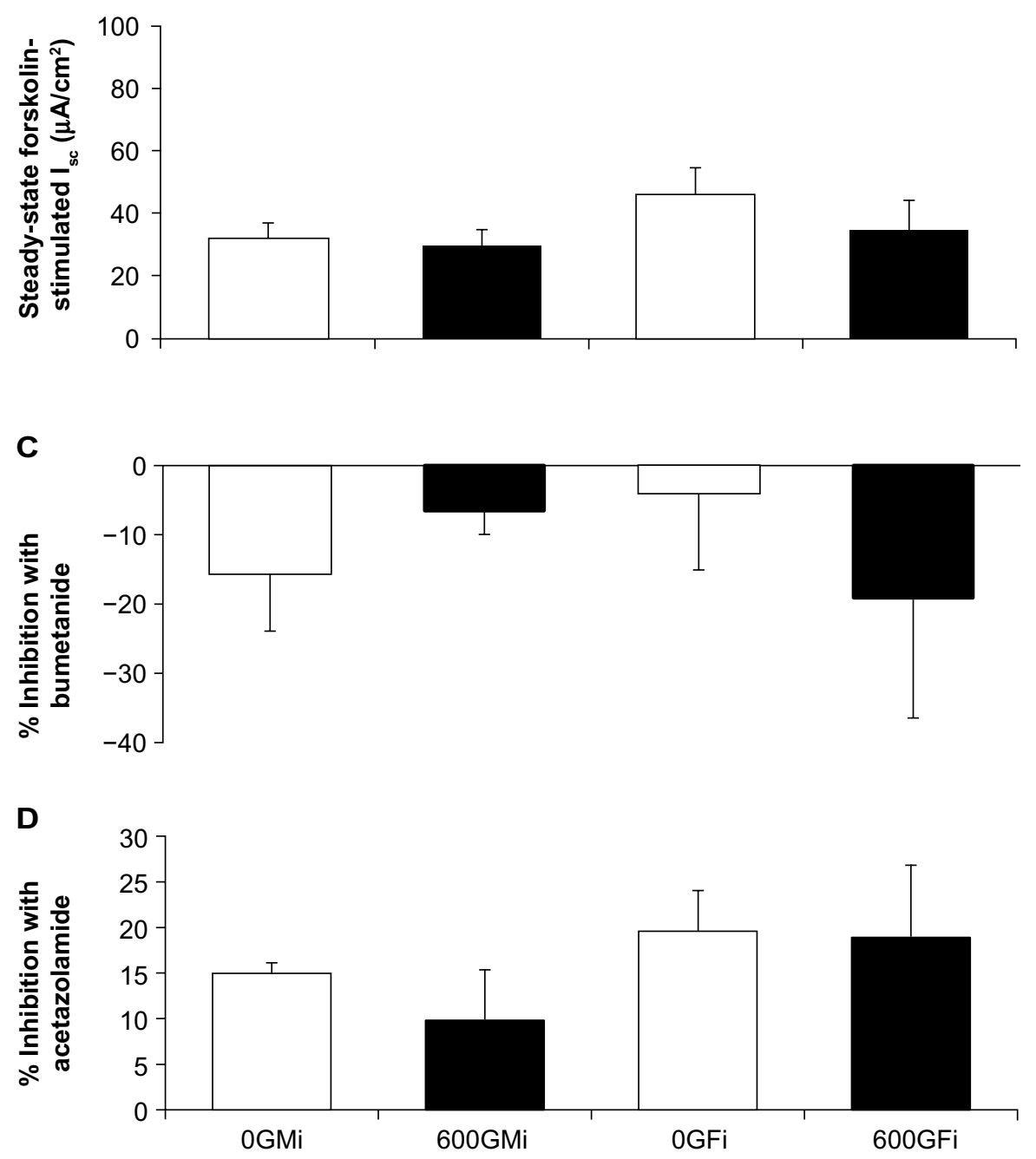

Figure 4 Effect of genistein injections on average $I_{s c}$ in jejunum from RII7H mice.

Notes: (A) Average basal I fsc from the RI I 7H male (M) and female (F) mice, injected with either 600Gi or 0Gi for I week. (B) Average steady-state forskolin-stimulated (I0 $\mu M$, bilateral) $I_{s c}$ from male and female mice injected with $600 \mathrm{Gi}$ or $0 \mathrm{Gi}$ for I week. (C) Percentage inhibition of steady-state forskolin-stimulated $I_{s c}$ by bumetanide (I00 $\mu \mathrm{M}$, serosal). (D) Percentage inhibition of steady-state forskolin-stimulated $\mathrm{I}_{\mathrm{sc}}$ by acetazolamide (100 $\mu \mathrm{M}$, bilateral). Values are mean \pm SEM.

Abbreviations: $I_{s c}$, short circuit current; $600 \mathrm{Gi}$, genistein injection $600 \mathrm{mg}$ genistein $/ \mathrm{kg}$ body weight; 0Gi, dimethyl sulfoxide control; SEM, standard error of the mean.

compared to males fed $600 \mathrm{Gd}(336 \pm 71 \mathrm{ng} / \mathrm{mL}, \mathrm{n}=9)$, which may contribute to the disparity and sex-dependent basal $\mathrm{I}_{\mathrm{sc}}$ increases. However, in these R117H mice, compared to our previous Wt-mice studies, it is notable and distinct that increases in serum genistein do not correlate consistently with increases in basal $\mathrm{I}_{\mathrm{sc}}$. This disparity may be a consequence of the fact that the serum genistein levels attained in R117H mice are not comparable to those in Wt mice. Clearance rates of serum genistein may well be different between R117H and Wt mice, in addition to sex-dependent clearance rates, 
A

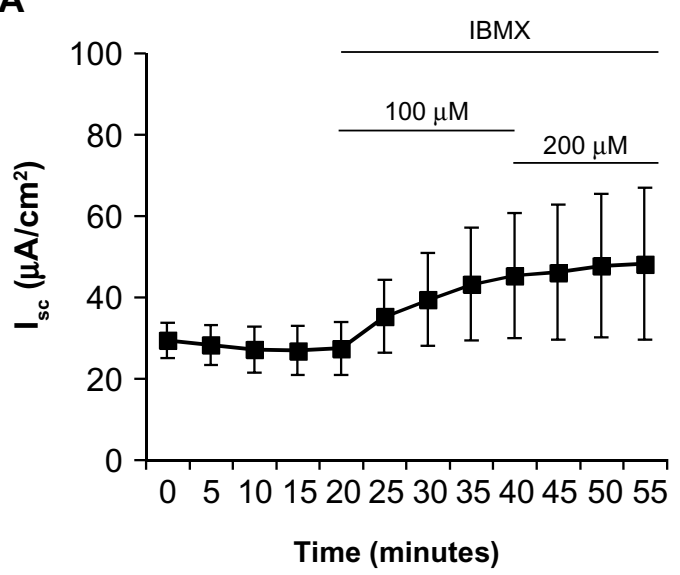

C

C

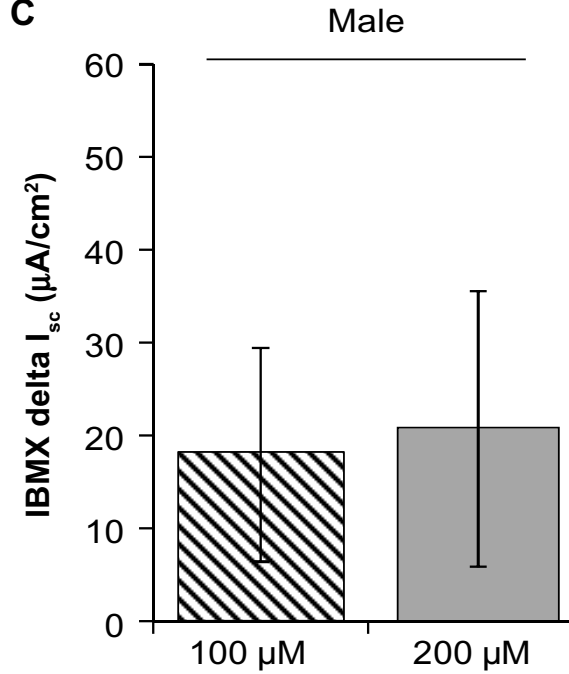

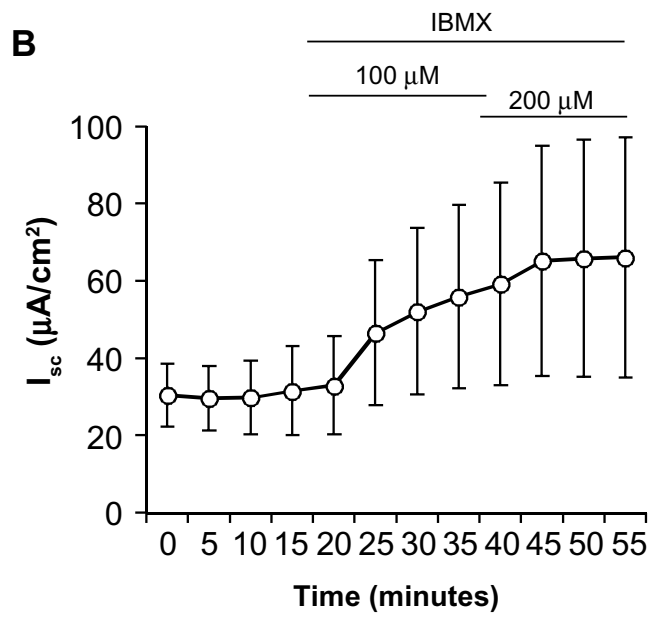

Female

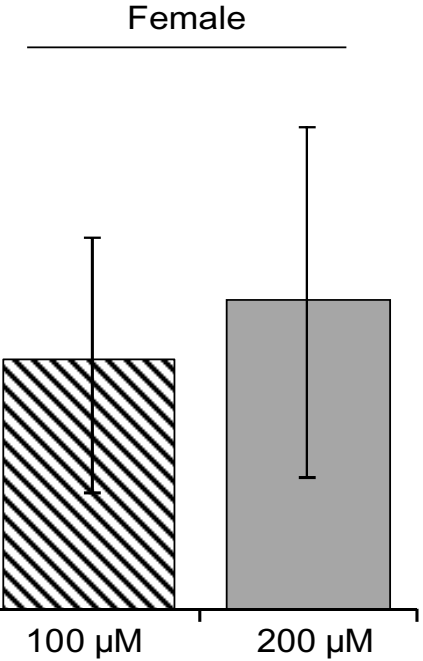

Figure 5 Effect of the nonspecific phosphodiesterase enzyme inhibitor IBMX on basal I in jejunum from RII7H mice.

Notes: (A) Average data from RI I 7H males: basal I ${ }_{s c}(0-20$ minutes); addition of bilateral IBMX (I00 $\mu$ M and $200 \mu M)$ is shown ( $\left.n=6\right)$. (B) Average data from RI I 7H females: basal $I_{s c}(0-20$ minutes); addition of bilateral IBMX (I00 $\mu M$ and $200 \mu M)$ is shown $(n=6)$. (C) Average change in (delta) I following addition of I00 $\mu$ M and $200 \mu M$ IBMX (bilateral) to jejunum of male and female RII $7 \mathrm{H}$ mice ( $n=6$ per group).

Abbreviations: $I_{\mathrm{sc}}$, short circuit current; IBMX, 3-isobutyl-I-methylxanthine.

Table 2 Effect of genistein on jejunum morphology

\begin{tabular}{lllll}
\hline & Villi length $(\mu \mathrm{m})$ & Crypt depth $(\mu \mathrm{m})$ & Goblet cells per villus & Goblet cells per crypt \\
\hline Male, 0Gd (8) & $343.9 \pm 15.4$ & $106.7 \pm 5.4$ & $2.4 \pm 0.7$ & $0.8 \pm 0.3$ \\
Male, 600Gd (8) & $354.3 \pm 23.1$ & $104.2 \pm 7.3$ & $3.5 \pm 1.0$ & $1.2 \pm 0.5$ \\
Female, 0Gd (7) & $331.9 \pm 29.3$ & $101.8 \pm 4.2$ & $6.9 \pm 2.0 *$ & $2.2 \pm 0.8$ \\
Female responders, 600Gd (4) & $314.4 \pm 28.1$ & $93.5 \pm 13.8$ & $5.9 \pm 1.9$ & $2.3 \pm 1.3$ \\
Female nonresponders, 600Gd (4) & $326.2 \pm 24.9$ & $106.9 \pm 14.9$ & $5.5 \pm 1.5$ & $1.9 \pm 0.8$ \\
Male, 0Gi (5) & $400.2 \pm 15.9$ & $117.5 \pm 5.6$ & $2.8 \pm 1.1$ & $1.5 \pm 0.5$ \\
Male, 600Gi (5) & $390.2 \pm 23.5$ & $125.5 \pm 13.8$ & $1.4 \pm 0.3$ & $0.6 \pm 0.2$ \\
Female, 0Gi (5) & $358.4 \pm 32.3$ & $139.7 \pm 9.7$ & $2.4 \pm 0.4$ & $1.6 \pm 0.7$ \\
Female, 600Gi (5) & $396.5 \pm 44.5$ & $122.7 \pm 9.8$ & $2.6 \pm 0.9$ & $0.9 \pm 0.4$ \\
\hline
\end{tabular}

Notes: The following measures were taken in both female and male mice that were injected daily with $600 \mathrm{Gi}$ or $0 \mathrm{Gi}$ for I week or were fed $600 \mathrm{Gd}$ or $0 \mathrm{Gd}$ for 4 weeks. Data are expressed as mean \pm SEM. Numbers in parentheses are the numbers of mice per group. *Significantly different from male counterparts, $P<0.05$.

Abbreviations: $600 \mathrm{Gd}, 600 \mathrm{mg}$ genistein/kg diet; 0Gd, genistein-free diet; $600 \mathrm{Gi}, 600 \mathrm{mg}$ genistein/kg body weight; 0Gi, dimethyl sulfoxide control; SEM, standard error of the mean. 

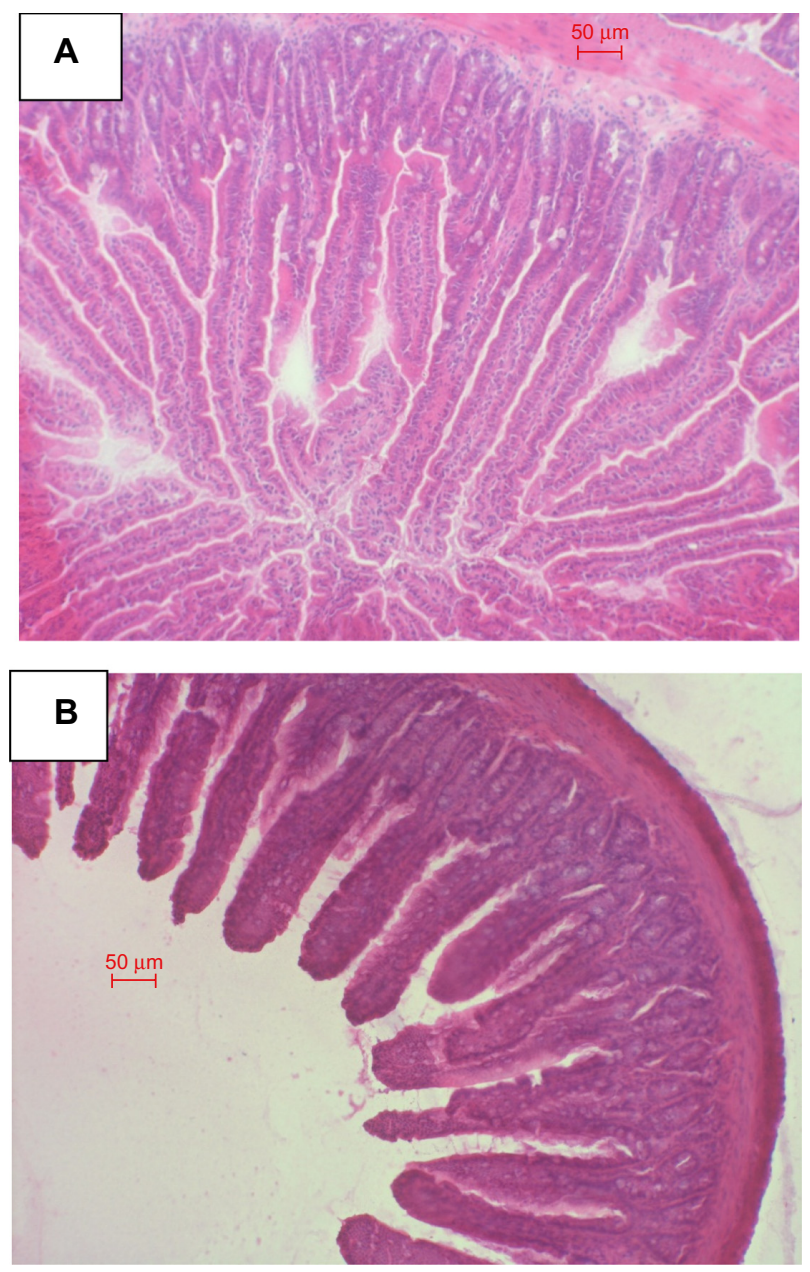

Figure 6 Representative sections from RII7H jejunum stained with hematoxylin and eosin.

Notes: (A) Typical section from a 0Gd-administered male RII7H mouse jejunum. (B) Typical section from a 600Gd-administered male RII $7 \mathrm{H}$ mouse jejunum. Images taken at $\times 10$ magnification.

Abbreviations: 600Gd, 600 mg genistein/kg diet; 0Gd, genistein-free diet.

because evidence suggests that after consuming the same genistein-rich diets, female mice have greater circulating levels than their male counterparts..$^{37,38}$

In the murine intestine, the major route for $\mathrm{Cl}^{-}$exit across the apical membrane is via the CFTR $\mathrm{Cl}^{-}$ channel, ${ }^{39-41}$ although it is widely accepted that other candidate pathways (ClC-2 and/or ClC-4) exist for this apical membrane $\mathrm{Cl}^{-}$exit. ${ }^{42,43}$ The presence of $\mathrm{ClC}-2$ and ClC-4 is thought to be responsible for the lack of severe intestinal impact observed in a subset of CF mice. ${ }^{43} \mathrm{In}$ addition, members of the family of $\mathrm{Ca}^{2+}$-activated $\mathrm{Cl}^{-}$ channels (CLCA), mCLCA2 and mCLCA3, have been proposed to be involved in intestinal function of both $\mathrm{CF}$ and Wt mice. ${ }^{44}$ Whether or not our observed increase in $I_{s c}$ following the 4-week genistein-feeding regimen in the subgroup of female R117H mice is due to activation of CLC channels remains to be seen.

Genistein's ability to improve epithelial function, namely, to increase epithelial secretion, has remained both intriguing and questionable. Mall et $\mathrm{al}^{6}$ suggested that genistein activated both Wt- and $\triangle$ F508-CFTR in oocytes and non-CF human tissue, yet they did not garner support for genistein's use as a pharmacological tool in CF. More recently, Yu et a ${ }^{45}$ demonstrated that combined application of curcumin with genistein did in fact synergistically rescue the gating defect associated with G551D-CFTR. Various other CFTR activators have been tested by several laboratories in the past decade. Such small-molecule correctors have varying effects on CF epithelia and, not surprisingly, appear to be CF mutationdependent moieties. ${ }^{46}$ Caputo et a ${ }^{47}$ suggested that felodipine and PG-01 acted on the CFTR mutations E193K, G970R, and G551D, whereas the sulfonamide SF-01 was not as effective. A therapeutic potential has been hypothesized for the naturally occurring coumarin compound osthole, given its ability to stimulate $\Delta$ F508-CFTR-mediated $\mathrm{Cl}^{-}$secretion in colonic mucosa. ${ }^{48}$ In addition, the compound RP193 (a modified pyrrolo[2,3-b]pyrazine derivative) has been shown to potentiate $\Delta F 508$ - and G551D-CFTR activity in the presence of low forskolin concentrations in cell culture systems. ${ }^{49}$ Ivacaftor (VX-770) has been shown in vitro to increase $\Delta \mathrm{F} 508$ and G551D channel opening in recombinant cells, to increase $\mathrm{Cl}^{-}$secretion in human $\mathrm{CF}$ bronchial epithelia, ${ }^{50}$ to improve lung function indices in CF subjects who have the G551D mutation, ${ }^{51}$ and more recently, to effectively activate a wider range of CFTR gating mutations in vitro, eg, G1349D, S1255P, S1251N, G1244E, G551S, and G178R. ${ }^{52}$

Interestingly, the R117H CFTR mutation has received less attention in the field of potential candidate pharmacomodulators. This is likely a consequence of the fact that the R117H missense mutation has a combination of both conductance and gating dysfunction, thus functional rectification may be challenging. ${ }^{22,25}$ Utilizing a cell culture system, Clancy et $\mathrm{al}^{53}$ have previously shown activation of R117H CFTR by adenosine and its nucleotides. We conclude that given the variety of CFTR activators available, the mechanism(s) involved in the activation of CFTR (and its many mutated forms) are no doubt both numerous, and complex.

While the mechanism(s) underlying the genisteinmediated $(600 \mathrm{Gd})$ increase in jejunum anion secretion in the subpopulation of $\mathrm{R} 117 \mathrm{H}$ females is(are) currently unclear, our data suggest the following: 1) it is not a result of changes in intestinal morphology, ie, not related to changes in crypt 
depth (responders: $96.5 \pm 13.8 \mu \mathrm{m}, \mathrm{n}=4$, versus nonresponders: $106.9 \pm 14.9 \mu \mathrm{m}, \mathrm{n}=4$ ) or number of goblet cells in crypts (responders: $2.3 \pm 1.3, \mathrm{n}=4$, versus nonresponders: $1.9 \pm 0.8, \mathrm{n}=4$ ); 2 ) it is not related to change in body weight (ie, growth of those mice fed the $600 \mathrm{Gd}$ ); however, there was a trend for these responding mice to gain somewhat more weight at the end of the study (responders: $1.92 \pm 0.94 \mathrm{~g}, \mathrm{n}=6$, versus nonresponders: $1.36 \pm 0.25 \mathrm{~g}, \mathrm{n}=4) ; 3$ ) it is not related to changes in serum genistein levels (responders: $740 \pm 272 \mathrm{ng} / \mathrm{mL}, \mathrm{n}=3$, versus nonresponders: $1,095 \pm 592 \mathrm{ng} / \mathrm{mL}, \mathrm{n}=4)$; 4) it is related to an increase in $\mathrm{Cl}^{-}$secretion, as evidence by the significantly elevated bumetanide-sensitive $\mathrm{I}_{\mathrm{sc}}$ in responders versus nonresponders. This study provides the first evidence that consumption of dietary genistein (600Gd), a naturally occurring isoflavone, can mediate an increase in basal intestinal anion secretion in a population of $\mathrm{R} 117 \mathrm{H}$ female mice.

\section{Acknowledgments}

The authors thank Dr G Rottinghaus (Veterinary Medical Diagnostic Laboratory, University of Missouri-Columbia, MO, USA) for analysis of serum genistein. This work was supported by the Soy Health Research Program (to LA), the National Institutes of Health (grant number R15 DK07162501A2 to LA), and the Midwestern University intramural funds (to LA). We also gratefully acknowledge the CF Mouse Models Core of the Case Western Reserve University and thank Alma Wilson for maintaining the R117H mouse colony.

\section{Disclosure}

The authors report no conflicts of interest in this work.

\section{References}

1. Murphy PA. Phytoestrogen content of processed soybean products. Food Technol. 1982;36:60-64.

2. Al-Nakkash L, Hu S, Li M, Hwang T-C. A common mechanism for cystic fibrosis transmembrane conductance regulator protein activation by genistein and benzimidazolone analogs. J Pharmacol Exp Ther. 2001;296:464-472.

3. Moran O, Zegarra-Moran O. A quantitative description of the activation and inhibition of CFTR by potentiators: genistein. FEBS Lett. 2005;579:3979-3983.

4. Schmidt A, Hughes LK, Cai Z, et al. Prolonged treatment of cells with genistein modulates the expression and function of the cystic fibrosis transmembrane conductance regulator. Br J Pharmacol. 2008;153: 1311-1323.

5. Illek B, FIscher H, Santos GF, Widdicombe JH, Machen TE, Reenstra WW. cAMP-independent activation of CFTR $\mathrm{Cl}$ channels by the tyrosine kinase inhibitor genistein. Am J Physiol. 1995;268:C886-C893.

6. Mall M, Wissner A, Seydewitz HH, et al. Effect of genistein on native epithelial tissue from normal individuals and CF patients and on ion channels expressed in Xenopus oocytes. Br J Pharmacol. 2000;130:1884-1892.

7. Baker MJ, Hamilton KL. Genistein stimulates electrogenic $\mathrm{Cl}^{-}$secretion in the mouse jejunum. Am J Physiol. 2004;287:C1636-C1645.
8. Al-Nakkash L, Clarke LL, Rottinghaus GE, Chen YJ, Cooper K, Rubin LJ. Dietary genistein stimulates anion secretion across female murine intestine. J Nutr. 2006;136:2785-2790.

9. Chao P-C, Hamilton KL. Genistein stimulates electrogenic $\mathrm{Cl}^{-}$secretion via phosphodiesterase modulation in the mouse jejunum. Am J Physiol. 2009;297:C688-C698.

10. Tuo B, Wen G, Seidler U. Differential activation of the $\mathrm{HCO}_{3}^{-}$ conductance through the cystic fibrosis transmembrane conductance regulator anion channel by genistein and forskolin in murine duodenum. Br J Pharmacol. 2009;158:1313-1321.

11. Al-Nakkash L, Hwang T-C. Activation of CFTR by pharmacological modulators. Pediatr Pulmonol Suppl. 1997;13:Abstract \#68.

12. Hwang T-C, Wang F, Zeltwanger S, Yang I, Reenstra W. Genistein potentiates wild-type and ĐF508-CFTR channel activity. Am J Physiol. 1997:273:C988-C998.

13. Wang F, Zeltwanger S, Yang I, Nairn A, Hwang T-C. Actions of genistein on CFTR channel gating. J Gen Physiol. 1998;111:477-490.

14. Barnes S, Sfakianos J, Coward L, Kirk M. Soy isoflavonoids and cancer prevention. Underlying biochemical and pharmacological issues. $A d v$ Exp Med Biol. 1996;401:87-100.

15. Hsieh CY, Santell R, Haslam S, Helferich W. Estrogenic effects of genistein on the growth of estrogen receptor-positive human breast cancer (MCF-7) cells in vitro and in vivo. Cancer Res. 1998;58:3833-3838.

16. Xu X, Wang H, Murphy P, Cook L, Hendrich S. Daidzein is a more bioavailable soymilk isoflavone than is genistein in adult women. J Nutr. 1994;124:825-832.

17. Noël S, Strale PO, Dannhoffer L, et al. Stimulation of salivary secretion in vivo by CFTR potentiators in $\mathrm{Cftr}^{+/+}$and $\mathrm{Cftr}^{-/-}$mice. J Cyst Fibros. 2008;7:128-133.

18. Goddard CA, Evans M, Colledge W. Genistein activates CFTRmediated $\mathrm{Cl}^{-}$secretion in the murine trachea and colon. Am J Physiol. 2000;279:C383-C392.

19. Cuthbert A. Assessment of CFTR chloride channel openers in intact normal and cystic fibrosis murine epithelia. Br J Pharmacol. 2001;132: 659-668.

20. Al-Nakkash L, Batia L, Bhakta M, et al. Stimulation of murine intestinal secretion by daily genistein injections: gender-dependent differences. Cell Physiol Biochem. 2011;28:239-250.

21. Al-Nakkash L. Genistein stimulates jejunal chloride secretion via sexdependent, estrogen receptor or adenylate cyclase mechanisms. Cell Physiol Biochem. 2012;30:137-150.

22. Sheppard DN, Rich DP, Ostedgaard LS, Gregory RJ, Smith AE, Welsh MJ. Mutations in CFTR associated with mild-disease-form Cl-channels with altered pore properties. Nature. 1993;362:160-164.

23. Carson MR, Winter MC, Travis SM, Welsh MJ. Pyrophosphate stimulates wild-type and mutant cystic fibrosis transmembrane conductance regulator $\mathrm{Cl}^{-}$Channels. J Biol Chem. 1995;270:20466-20472.

24. Nichols DP, Ziady AG, Shank SL, Eastman JF, Davis PB. The triterpenoid CDDO limits inflammation in preclinical models of cystic fibrosis lung disease. Am J Physiol Lung Cell Mol Physiol. 2009;297: L828-L836.

25. de Nooijer RA, Nobel JM, Arets HG, et al. Assessment of CFTR function in homozygous R117H-7T subjects. $J$ Cyst Fibros. 2011;10: 326-332.

26. Lim CH, Bijvelds MJ, Nigg A, et al. Cholesterol depletion and genistein as tools to promote F508delCFTR retention as the plasma membrane. Cell Physiol Biochem. 2007;20:473-482.

27. Clarke LL, Harline MC. Dual role of CFTR in cAMP-stimulated $\mathrm{HCO}_{3}{ }^{-}$secretion across murine duodenum. Am J Physiol. 1998;274: G718-G726.

28. Grubb BR, Boucher RC. Enhanced colonic $\mathrm{Na}^{+}$absorption in cystic fibrosis mice versus normal mice. Am J Physiol. 1997;272:G393-G400.

29. Grubb BR. Ion transport across the jejunum in normal and cystic fibrosis mice. Am J Physiol. 1995;268:G505-G513.

30. Clarke LL, Grubb BR, Gabriel SE, Smithies O, Coller BH, Boucher RC. Defective epithelial chloride transport in a gene-targeted mouse model of cystic fibrosis. Science. 1992;257:1125-1128. 
31. Clarke LL, Harline MC. CFTR is required for cAMP inhibition of intestinal $\mathrm{Na}^{+}$absorption in a cystic fibrosis mouse model. Am J Physiol. 1996;270:G259-G267.

32. Sheldon RJ, Malarchik ME, Fox DA, Burks TF, Porreca F. Pharmacological characterization of neural mechanisms regulating mucosal ion transport in mouse jejunum. J Pharmacol Exp Ther. 1988;249:572-582.

33. Franke AA, Custer LJ, Wang W, Shi CY. HPLC analysis of isoflavonoids and other phenolic agents from human fluids. Proc Soc Exp Biol Med. 1998;217:263-273.

34. Hendrich S, Lee KW, Xu X, Wang HJ, Murphy PA. Defining food components as new nutrients. J Nutr. 1994;124:1789S-1792S.

35. Santell RC, Chang YC, Nair MG, Helferich WG. Dietary genistein exerts estrogenic effects upon the uterus, mammary gland and the hypothalamic/pituitary axis in rats. J Nutr. 1997;127:263-269.

36. Bhandari A, Crawford SE, Huang L, Reenstra WW. Effects of oral genistein in mice. Pediatr Pathol Mol Med. 2003;22:131-141.

37. Doerge DR, Twaddle NC, Banks EP, Jefferson WN, Newbold RR. Pharmacokinetic analysis in serum of genistein administered subcutaneously to neonatal mice. Cancer Lett. 2002;184:21-27.

38. Morris SM, Akerman GS, Warbritton AR, et al. Effect of dietary genistein on cell replication indices in C57BL6 mice. Cancer Lett. 2003;195:139-145.

39. Grubb BR. Ion transport across the normal and CF neonatal murine intestine. Am J Physiol. 1999;277:G167-G174.

40. Anderson MP, Welsh MJ. Calcium and cAMP activate different chloride channels in the apical membrane of normal and cystic fibrosis epithelia. Proc Natl Acad Sci U S A. 1991;88:6003-6007.

41. Clarke LL, Grubb BR, Yankaskas JR, Cotton CU,McKenzieA, Boucher RC. Relationship of a non-cystic fibrosis transmembrane conductance regulator-mediated chloride conductance to organ-level disease in Cftr(-/-) mice. Proc Natl Acad Sci U S A. 1994;91:479-483.

42. Rozmahel R, Wilschanski M, Matin A, et al. Modulation of disease severity in cystic fibrosis transmembrane conductance regulator deficient mice by a secondary genetic factor. Nat Genet. 1996;12:280-287.
43. Gyomorey K, Garami E, Galley K, Rommens JM, Bear CE. Non-CFTR chloride channels likely contribute to secretion in the murine small intestine. Pflugers Arch. 2001;443:S103-S106.

44. Leverkoehne I, Holle H, Anton F, Gruber AD. Differential expression of calcium-activated chloride channels (CLCA) gene family members in the small intestine of cystic fibrosis mouse models. Histochem Cell Biol. 2006;126:239-250.

45. Yu YC, Miki H, Nakamura Y, et al. Curcumin and genistein additively potentiate G551D-CFTR. J Cyst Fibros. 2011;10:243-252.

46. Pedemonte N, Lukacs GL, Du K, et al. Small-molecule correctors of defective deltaF508 cellular processing identified by high throughput screening. J Clin Invest. 2005;115:2564-2571.

47. Caputo A, Hinzpeter A, Caci E, et al. Mutation-specific potency and efficacy of cystic fibrosis transmembrane conductance regulator chloride channel potentiators. J Pharmacol Exp Ther. 2009;330:783-791.

48. Yang H, Xu LN, Sui YJ, et al. Stimulation of airway and intestinal mucosal secretion by natural coumarin CFTR activators. Front Pharmacol. 2011;2:1-5.

49. Dannhoffer L, Billet A, Jollivet M, Melin-Heschel P, Faveau C, Becq F. Stimulation of wild-type, F508del- and G551D-CFTR chloride channels by non-toxic modified pyrrolo[2,3-b]pyrazine derivatives. Front Pharmacol. 2011;2:1-10.

50. Van Goor F, Hadida S, Grootenhuis PDJ, et al. Rescue of CF airway epithelial cell function in vitro by a CFTR potentiator, VX-770. Proc Natl Acad Sci U S A. 2009;106:18825-18830.

51. Accurso FJ, Rowe SM, Clancy JP, et al. Effect of VX-770 in persons with cystic fibrosis and the G551D-CFTR mutation. $N$ Engl J Med. 2010;363:1991-2003.

52. Yu H, Burton B, Huang CJ, et al. Ivacaftor potentiation of multiple CFTR channels with gating mutations. J Cyst Fibros. 2012;11:237-245.

53. Clancy JP, Ruiz FE, Sorscher EJ. Adenosine and its nucleotides activate wild-type and $\mathrm{R} 117 \mathrm{H} \mathrm{CFTR}$ through an $\mathrm{A}_{2 \mathrm{~B}}$ receptor-coupled pathway. Am J Physiol. 1999;276:C361-C369.
Clinical and Experimental Gastroenterology

\section{Publish your work in this journal}

Clinical and Experimental Gastroenterology is an international, peerreviewed, open access journal, publishing all aspects of gastroenterology in the clinic and laboratory, including: Pathology, pathophysiology of gastrointestinal disease; Investigation and treatment of gastointestinal disease; Pharmacology of drugs used in the alimentary tract;

\section{Dovepress}

Immunology/genetics/genomics related to gastrointestinal disease. This journal is indexed on CAS. The manuscript management system is completely online and includes a very quick and fair peer-review system. Visit http://www.dovepress.com/testimonials.php to read real quotes from published authors. 